\title{
Influence of YEA-SACC 1026 Probiotic on Some Production and Consumption Indices in Chicken Broilers
}

\author{
Ionel TOADER*, Aurel ŞARA, Mihai BENŢEA, Marius CIOLTEA
}

Faculty of Animal Science and Biotechnologies, University of Agricultural Sciences and Veterinary Medicine, 3-5 Mănăștur Street, 400372 Cluj-Napoca, Romania

* corresponding author: tehnicianionel@gmail.com

Bulletin UASVM Animal Science and Biotechnologies 74(1)/ 2017

Print ISSN 1843-5262; Electronic ISSN 1843-536X

DOI:10.15835/buasvmcn-asb: 12289

\begin{abstract}
The researches followed the effects of YEA-SACC 1026 probiotic product on some production and consumption indices in chicken broilers. The researches were effected on 75 meat chickens of Ross-308 hybrid, which were grouped in three lots of 25 capita/lot during 42 days. In the Lot 1(E), for 42 days, in the mixed fodder was added YEA-SACC 1026 probiotic in proportion of $0.1 \%$ in breeding phase I (1-14 days), of $0.1 \%$ in phase II (15-35 days) and $0.1 \%$ in phase III (36-42 days). In the Lot 2(E), for 42 days, in the mixed fodder was added YEA-SACC 1026 probiotic in proportion of $0.25 \%$ in breeding phase I (1-14 days), of $0.25 \%$ in phase II (15-35 days) and $0.25 \%$ in phase III (36-42 days). The chickens of both lots were weighted at the beginning of experiment and after that weekly being calculated the average body weight, average daily gain, fodder consumption and fodder conversion index. The use of YEA-SACC 1026 probiotic in lot 1(E) determined an increase of body weight with 16.26\%, of average daily gain with $15.55 \%$ and the fodder conversion index was reduced with $29.16 \%$ given to Control Lot. On the second place was situated the Lot 2(E), in witch was administered $0.25 \%$ of YEA-SACC 1026 probiotic, with an increase of body weight of $8.32 \%$, of average daily gain with $7.54 \%$ and the fodder conversion index was reduced with $21.78 \%$ given to Control Lot. These superior results, registered in meat chickens from Lot 1(E) YEA-SACC 1026 probiotic $-0.1 \%$ and Lot 2(E) YEA-SACC 1026 probiotic $-0.25 \%$, confirm the favourable influence of the two probiotics on chicken broilers' performances.
\end{abstract}

Keywords: meat chickens, YEA-SACC 1026, production performances

\section{INTRODUCTION}

Having in view the fact that starting with January 1, 2006 European Union forbidden the use of breeding promoters based on antibiotics in farm animal fodder, it became necessary to find some alternatives, and these ones could be probiotics. Such a probiotic is YEA-SACC 1026, which has an important role in fodder assimilation degree and its efficiency. The living culture of Saccharomyces cerevisiae, grown on a medium of yellow maize, malt and treacle, has the next composition: minimum $28 \%$ of pure protein, minimum $6 \%$ of pure fat, maximum $14 \%$ of pure fiber, maximum $8 \%$ of dry substance and contains minimum 5 millions of cells/gram. The product high concentration degree leads to a reduced daily dosage administration. Hereby, in meat chickens and generally in poultry, the administration dosage is of $1 \mathrm{~kg}$ of probiotic per 1 tone of fodder.

Concerning the performances of this product, some researchers as Paryad et al. (2008) have observed that administration of YEA-SACC 1026 probiotic, in different doses in meat chickens, registered the best results in experimental 
lots as regards the chickens' body weight, the fodder conversion index and their healthy status comparatively to control lot.

Gheisari et al. (2010), after administration of living yeast in dose of $0.1 \%$ in meat chickens, obtained the best results concerning body weight (2780.87 g given to control lot of $2762.179 \mathrm{~g}$ ), average daily gain (55.93 g given to control lot with $55.57 \mathrm{~g}$ ) and fodder conversion index (1.82 given to control lot with 1.87) comparatively with control lot and other experimental lots in which administered living yeast in doses of $0.2 \%$ and $0.3 \%$.

Another researchers, as Gao et al. (2008), administered living Saccharomyces cerevisiae in dose of $2.5 \%$ for meat chickens and obtained the best results for body weight (2459 g given to control lot with $2378 \mathrm{~g}$ ), average daily gain (57.5 g given to control lot with $55.6 \mathrm{~g}$ ) and fodder conversion (1.95 given to 2.03) comparatively with control lot and other experimental ones.

\section{MATERIALS AND METHODS}

The researches were effected during September and October 2015 inside the Biobasis of Poultry Discipline from Department II Technological Sciences of Faculty of Animal Science and Biotechnologies of UASVM Cluj-Napoca, on a number of 75 meat chickens of Ross-308 hybrid, grouped in three lots of 25 capita/lot, during 42 days. For the Control Lot was administered simple mixed fodder having the same protein level as in the lots $1(\mathrm{E})$ and 2(E). The administered mixed fodder ensured $3030 \mathrm{kcal} \mathrm{ME} / \mathrm{kg}$ in the first phase, $3134.8 \mathrm{kcal} \mathrm{ME} / \mathrm{kg}$ in the second phase and 3144 $\mathrm{kcal} \mathrm{ME} / \mathrm{kg}$ in the finishing phase. As concerns the level of crude protein, it was $22.76 \%$ in the first phase, $21.31 \%$ in the second phase and $19.94 \%$ in the third phase, ensuring a good biological value and being in concordance with energetic level of fodder.

In the Lot $1(E)$, for 42 days, in the mixed fodder was added YEA-SACC 1026 probiotic in proportion of $0.1 \%$ in breeding phase I (1-14 days), of $0.1 \%$ in phase II (15-35 days) and $0.1 \%$ in phase III (36-42 days). In the Lot 2(E), for 42 days, in the mixed fodder was added YEA-SACC 1026 probiotic in proportion of $0.25 \%$ in breeding phase I (114 days), of $0.25 \%$ in phase II (15-35 days) and $0.25 \%$ in phase III (36-42 days). The fodder was administered ad-libitum. The chickens of both lots were weighted at the beginning of experiment and subsequent weekly being calculated the average body weight, average daily gain, fodder consumption and fodder conversion index.

During the experimental researches, the biological material do not received any vaccine or medication treatment.

The experimental data were statistically analysed by Student test and GraphPad InStat ver. 3.10 program.

\section{RESULTS AND DISCUSSION}

The average values and variability of body weight, in meat chickens on breeding phase I (114 days), are presented in Table 1. Comparing the data, it can be observed that there are not significant differences of body weight among the three lots in the beginning of experiment, at 7 days, but at 14 days appear significant differences between L1(E) and L(M).

The average daily gain obtained in breeding phase I is presented in Table 2. The difference of average daily gain realized during 14 days is greater in experimental lots than the control one. In L1(E), after the breeding phase I, is observed a difference of $9.18 \%$ given to $\mathrm{L}(\mathrm{M})$.

The average values and variability of body weight in meat chickens on breeding phase II (1535 days) are presented in Table 3. Gao et al. (2008) obtained at 21 days age an average body weight of $757.9 \mathrm{~g}$ with probiotic supplement of Yeast culture $2.5 \mathrm{~g} / \mathrm{kg}$ of diet. This average body weight, compared to our data (804.2 $\mathrm{g}$ in L(M), $848.92 \mathrm{~g}$ in L1(E) and $839.56 \mathrm{~g}$ in L2(E)), was significantly reduced, maybe because the probiotic supplement was not so benefic in the metabolic process.

At 28 days, there are observed significant differences between lots L1(E) and L2(E). From the data of Table 3 we can say that there are distinctive significant differences between L1(E) and $\mathrm{L}(\mathrm{M})$, but there are not significant differences between L2(E) and L(M). The gain difference between L2(E) and L(M) is only of $19.6 \mathrm{~g}$, and between experimental lots is only of $82.88 \mathrm{~g}$. From the presented data comes out that the effect of used probiotic (YEA/SACC 1026) is most efficient in doses of $0.1 \%$ in phase II.

The average daily gain realized in breeding phase II is presented in Table 4. As can be observed from data of Table 4, in Lot L1(E) was obtained an increase of average daily gain until 28 days of 
Tab. 1. Average values and variability of body weight in broiler chickens during 1-14 days (g/capita)

\begin{tabular}{|c|c|c|c|c|c|c|}
\hline \multirow[t]{2}{*}{ Age (days) } & \multicolumn{2}{|c|}{$\begin{array}{l}\mathrm{L}(\mathrm{M}) \\
\mathrm{n}=25\end{array}$} & \multicolumn{2}{|c|}{$\begin{array}{c}\mathrm{L} 1(\mathrm{E}) \\
\mathrm{n}=25 \\
\text { YEA-SACC1026 0.1\% }\end{array}$} & \multicolumn{2}{|c|}{$\begin{array}{c}\mathrm{L} 2(\mathrm{E}) \\
\mathrm{n}=25 \\
\text { YEA-SACC1026 } 0.25 \%\end{array}$} \\
\hline & $\mathrm{X} \pm \mathrm{S}_{\mathrm{v}}$ & $\mathrm{V} \%$ & $\mathrm{X} \pm \mathrm{S}_{\mathrm{v}}$ & V\% & $\mathrm{X} \pm \mathrm{S}_{\mathrm{v}}$ & V\% \\
\hline at 1 day & $43.6 \pm 0.62$ & 7.16 & $45.12 \pm 0.43$ & 4.72 & $44.32 \pm 0.53$ & 5.93 \\
\hline at 7 days & $174.2 \pm 2.43$ & 6.99 & $182.68 \pm 2.05$ & 5.60 & $179.36 \pm 1.94$ & 5.40 \\
\hline$\frac{\text { at } 14 \text { days }}{0.05 \text { - insignific }}$ & $\frac{420.6 \pm 6.35}{\text { differences; }}$ & 7.55 & $451.72 * \pm 7.07$ & 7.83 & $431.56 \pm 4.52$ & 5.23 \\
\hline
\end{tabular}

Tab. 2. Evolution of average gain in meat chickens during breeding phase I

\begin{tabular}{cccccc}
\hline $\begin{array}{c}\text { Age } \\
\text { (days) }\end{array}$ & U.M & $\begin{array}{c}\text { L (M) } \\
\mathrm{n}=25\end{array}$ & $\begin{array}{c}\text { L1(E) } \\
\mathrm{n}=25\end{array}$ & $\begin{array}{c}\text { L2(E) } \\
\mathrm{n}=25\end{array}$ \\
& YEA-SACC1026 0.1\% & YEA-SACC1026 0.25\% \\
\hline \multirow{3}{*}{$\begin{array}{c}\text { Phase I } \\
(1-14 \text { days) }\end{array}$} & \multirow{2}{*}{ at 7 days } & $\mathrm{g}$ & $\mathbf{1 3 0 . 6}$ & $\mathbf{1 3 7 . 5 6}$ & $\mathbf{1 3 5 . 0 4}$ \\
\cline { 2 - 6 } & \multirow{2}{*}{ at 14 days } & $\mathrm{g}$ & 100 & 105.32 & 103.39 \\
\cline { 2 - 6 } & & $\mathbf{2 4 6 . 4}$ & $\mathbf{2 6 9 . 0 4}$ & $\mathbf{2 5 2 . 2}$ \\
\hline
\end{tabular}

Tab. 3. Average values and variability of body weight in broiler chickens during 15-35 days (g/ capita)

\begin{tabular}{|c|c|c|c|c|c|c|}
\hline \multirow[t]{2}{*}{ Age (days) } & \multicolumn{2}{|l|}{$\begin{array}{l}\mathrm{L}(\mathrm{M}) \\
\mathrm{n}=25\end{array}$} & \multicolumn{2}{|c|}{$\begin{array}{c}\mathrm{L} 1(\mathrm{E}) \\
\mathrm{n}=25 \\
\text { YEA-SACC1026 0.1\% }\end{array}$} & \multicolumn{2}{|c|}{$\begin{array}{c}\mathrm{L} 2(\mathrm{E}) \\
\mathrm{n}=25 \\
\text { YEA-SACC1026 } 0.25 \%\end{array}$} \\
\hline & $\mathrm{X} \pm \mathrm{S}_{\mathrm{v}}$ & $\mathrm{V} \%$ & $\mathrm{X} \pm \mathrm{S}_{\mathrm{v}}$ & $\mathrm{V} \%$ & $\mathrm{X} \pm \mathrm{S}_{\mathrm{v}}$ & V\% \\
\hline at 15 days & $420.6 \pm 6.35$ & 7.55 & $451.72^{*} \pm 7.07$ & 7.83 & $431.56 \pm 4.52$ & 5.23 \\
\hline at 21 days & $804.2 \pm 10.52$ & 6.54 & $848.92 \pm 15.18$ & 8.94 & $839.56 \pm 10.53$ & 6.27 \\
\hline at 28 days & $1313.6 \pm 19.53$ & 7.43 & $1426.76^{* *} \pm 24.82$ & 8.71 & $1348.84 \pm 17.41$ & 6.45 \\
\hline at 35 days & $1932.76 \pm 43.73$ & 11.31 & $2035.24 * \pm 41.53$ & 10.20 & $1952.36 \pm 30.93$ & 7.92 \\
\hline
\end{tabular}

Tab. 4. Evolution of average gain in meat chickens during breeding phase II

\begin{tabular}{|c|c|c|c|c|c|}
\hline \multicolumn{2}{|c|}{ Age (days) } & U.M & $\begin{array}{l}\mathrm{L}(\mathrm{M}) \\
\mathrm{n}=25\end{array}$ & $\begin{array}{c}\mathrm{L} 1(\mathrm{E}) \\
\mathrm{n}=25 \\
\text { YEA-SACC1026 0.1\% }\end{array}$ & $\begin{array}{c}\mathrm{L} 2(\mathrm{E}) \\
\mathrm{n}=25 \\
\text { YEA-SACC1026 } 0.25 \%\end{array}$ \\
\hline \multirow{6}{*}{$\begin{array}{c}\text { Phase II } \\
\text { (15-35 days) }\end{array}$} & \multirow{2}{*}{ at 21 days } & $\mathrm{g}$ & 383.6 & 397.2 & 408 \\
\hline & & $\%$ & 100 & 103.54 & 106.36 \\
\hline & \multirow{2}{*}{ at 28 days } & $\mathrm{g}$ & 509.4 & 577.84 & 509.28 \\
\hline & & $\%$ & 100 & 113.43 & 99.97 \\
\hline & \multirow{2}{*}{ at 35 days } & $\mathrm{g}$ & 619.16 & 608.48 & 603.52 \\
\hline & & $\%$ & 100 & 98.27 & 97.47 \\
\hline
\end{tabular}


$+13.43 \%$, and after it decreases to $-1.73 \%$ given to $\mathrm{L}(\mathrm{M})$ at 35 days.In the lot L2(E) is observed an increase of average daily gain of $+6.36 \%$ at 21 days given to $\mathrm{L}(\mathrm{M})$, followed by a decrease of $-0.03 \%$ at 28 days and $-2.53 \%$ at 35 days.

In the breeding phase III, from 36 days to 42 days, the evolution of average body weight is presented in Table 5. In Table 5 can be observed that differences among experimental lots and control one are different significant. The very significant differences from phase II presented in Table 5 are doe to replacement in this period of "the coccidiostatic" from fodder composition with mentioned probiotics.

Gao et al. (2008) obtained at 42 days age an average body weight of $2459.0 \mathrm{~g}$ with probiotic supplement of Yeast culture $2.5 \mathrm{~g} / \mathrm{kg}$ of diet. This value was inferior to those one obtained by us in lot L1(E), respectively 2510.4 g. Once again, the explanation could be the reduced effect of probiotic supplement when it was added as $2.5 \mathrm{~g} /$ $\mathrm{kg}$ of diet.

The average daily gain (Tab. 6) was greater for experimental lots. From the data presented in Table 6 comes out that in final breeding phase III (finishing) the average daily gain was of $109.83 \%$ in L1(E) greater than in L(M) and of $70.72 \%$ in $\mathrm{L} 2(\mathrm{E})$ given to $\mathrm{L}(\mathrm{M})$. The administered fodder was the same in all three lots, as was presented in Material and Methods chapter.

The average fodder consumption, on breeding phase I in all 3 experimental lots, is presented in Table 7.

Tab. 5. Average values and variability of body weight in broiler chickens during 36-42 days (g/ capita)

\begin{tabular}{|c|c|c|c|c|c|c|}
\hline \multirow[t]{2}{*}{ Age (days) } & \multicolumn{2}{|c|}{$\begin{array}{l}\mathrm{L}(\mathrm{M}) \\
\mathrm{n}=25\end{array}$} & \multicolumn{2}{|c|}{$\begin{array}{c}\mathrm{L} 1(\mathrm{E}) \\
\mathrm{n}=25 \\
\text { YEA-SACC1026 } 0.1 \%\end{array}$} & \multicolumn{2}{|c|}{$\begin{array}{c}\mathrm{L} 2(\mathrm{E}) \\
\mathrm{n}=25 \\
\text { YEA-SACC1026 } 0.25 \%\end{array}$} \\
\hline & $\mathrm{X} \pm \mathrm{S}_{\mathrm{x}}$ & V\% & $\mathrm{X} \pm \mathrm{S}_{\mathrm{v}}$ & V\% & $\mathrm{X} \pm \mathrm{S}_{\mathrm{v}}$ & V\% \\
\hline at 36 days & $1932.76 \pm 43.73$ & 11.31 & $2035.24^{*} \pm 41.53$ & 10.20 & $1952.36 \pm 30.93$ & 7.92 \\
\hline $\begin{array}{l}\text { at } 42 \text { days } \\
p<0.05 \text { - signifi } \\
* \text {, } p<0.001 \text { - ver }\end{array}$ & $\begin{array}{l}2159.2 \pm 33.23 \\
\text { differences; }{ }^{* *}, \mathrm{p}<0 \\
\text { mificant differences }\end{array}$ & $\frac{7.69}{\text { distinct }}$ & $\frac{2510.4^{* * *} \pm 43.06}{\text { ignificant differences; }}$ & 8.58 & $2338.96^{* * *} \pm 42.45$ & 9.07 \\
\hline
\end{tabular}

Tab. 6. Evolution of average gain in meat chickens during breeding phase III

\begin{tabular}{|c|c|c|c|c|c|}
\hline \multicolumn{2}{|c|}{ Age (days) } & U.M & $\begin{array}{l}\mathrm{L}(\mathrm{M}) \\
\mathrm{n}=25\end{array}$ & $\begin{array}{c}\mathrm{L} 1(\mathrm{E}) \\
\mathrm{n}=25 \\
\text { YEA-SACC1026 } 0.1 \%\end{array}$ & $\begin{array}{c}\mathrm{L} 2(\mathrm{E}) \\
\mathrm{n}=25 \\
\text { YEA-SACC1026 } 0.25 \%\end{array}$ \\
\hline \multirow{4}{*}{$\begin{array}{c}\text { Phase II } \\
\text { (36-42 days) }\end{array}$} & \multirow{2}{*}{ at 36 days } & g & 619.16 & 608.48 & 603.52 \\
\hline & & $\%$ & 100 & 98.27 & 97.47 \\
\hline & \multirow{2}{*}{ at 42 days } & $\mathrm{g}$ & 226.44 & 475.16 & 386.6 \\
\hline & & $\%$ & 100 & 209,83 & 170.72 \\
\hline
\end{tabular}

Tab. 7. Evolution of fodder consumption in broiler chickens during breeding phase I (1-14 days)

\begin{tabular}{cccccc}
\hline \multirow{2}{*}{ Age (days) } & U.M & $\begin{array}{c}\mathrm{L}(\mathrm{M}) \\
\mathrm{n}=25\end{array}$ & $\begin{array}{c}\mathrm{L} 1(\mathrm{E}) \\
\mathrm{n}=25\end{array}$ & $\begin{array}{c}\mathrm{L} 2(\mathrm{E}) \\
\mathrm{n}=25\end{array}$ \\
& YEA-SACC1026 0.1\% & YEA-SACC1026 0.25\% \\
\cline { 2 - 6 } Phase I & at 7 days & $\mathrm{g}$ & 37.71 & 37.14 & 36.57 \\
\cline { 2 - 6 }$(1-14$ days $)$ & $\begin{array}{c}\text { Average } \\
\text { consumption } \\
\text { on phase I }\end{array}$ & $\mathrm{g}$ & $\mathbf{3 7 . 7 1}$ & $\mathbf{3 8 . 1 4}$ & 38.97 \\
\hline
\end{tabular}


The fodder consumption in the first 7 days was smaller in experimental lots and greater in control one, but after 7 days the fodder consumption increased in experimental lots and remained constant in control one.

The evolution of fodder consumption on breeding phase II is presented in Table 8 . The fodder consumption in this breeding phase II is smaller in experimental lots given to control one starting with 28 days until 35 days, but the average consumption on breeding phase II is almost equal between the two experimental lots.

Gao et al. (2008), during 22-42 days with probiotic supplement of Yeast culture $2.5 \mathrm{~g} / \mathrm{kg}$ of diet, obtained an average fodder consumption of $176.1 \mathrm{~g} / \mathrm{bird}$ per day, which was significantly increased compared to our data, and during entire experimental period an average consumption of $112.2 \mathrm{~g} / \mathrm{bird}$ per day, which was inferior compared to our data.

In Table 9 is presented the fodder consumption during finishing period. The fodder conversion index was superior in lot L1(E) given to control one with $29.16 \%$, and in lot L2(E) it was superior with $21.78 \%$ given to control one, as is presented in Table 10. The analysis of these fodder conversion indices shows the efficiency of YEA-SACC 1026 probiotic.

Gheisari and Kholeghipour (2010), after administration of powdery living yeast in dose of $0.1 \%$ in meat chickens, obtained the best results concerning body weight (2775.77 g given to control lot of $2762.17 \mathrm{~g}$ ), average daily gain (55.80 g given to control lot with $55.57 \mathrm{~g}$ ) and fodder conversion index (1.88 given to control lot with 1.87) comparatively with control lot and other experimental lots in which administered living yeast in doses of $0.2 \%$ and $0.3 \%$.

Another researchers, as Gao et al. (2008), administered living Saccharomyces cerevisiae in dose of $2.5 \%$ for meat chickens and obtained the best results for average daily gain ( $57.5 \mathrm{~g}$ given to control lot with $55.6 \mathrm{~g}$ ) and fodder conversion (1.95 given to 2.03) comparatively with control lot and other experimental ones.

The analysis of these fodder conversion indices shows the efficiency of YEA-SACC 1026 probiotic, but the administered doses must be proper depending on species, age and especially on diet.

Tab. 8. Evolution of fodder consumption in broiler chickens during breeding phase II (15-35 days)

\begin{tabular}{cccccc}
\hline \multirow{2}{*}{ Age (days) } & U.M & $\begin{array}{c}\mathrm{L}(\mathrm{M}) \\
\mathrm{n}=25\end{array}$ & $\begin{array}{c}\mathrm{L} 1(\mathrm{E}) \\
\mathrm{n}=25\end{array}$ & $\begin{array}{c}\mathrm{L} 2(\mathrm{E}) \\
\mathrm{n}=25\end{array}$ \\
& YEA-SACC1026 0.1\% & YEA-SACC1026 0.25\% \\
\hline & at 21 days & $\mathrm{g}$ & 64.71 & 64.96 & 65.31 \\
\cline { 2 - 6 } Phase II & at 28 days & $\mathrm{g}$ & 128.02 & 122.14 & 125.17 \\
\cline { 2 - 6 }$(15-35$ days) & at 35 days & $\mathrm{g}$ & 159.69 & 158.24 & 156.23 \\
\cline { 2 - 6 } & $\begin{array}{c}\text { Average } \\
\text { consumption } \\
\text { on phase II }\end{array}$ & $\mathrm{g}$ & 117.23 & 115.11 & 115.57 \\
\hline
\end{tabular}

Tab. 9. Evolution of fodder consumption in broiler chickens during breeding phase III (36-42 days)

\begin{tabular}{ccccc}
\hline Age (days) & U.M & $\begin{array}{c}\text { L (M) } \\
\mathrm{n}=25\end{array}$ & $\begin{array}{c}\text { L1(E) } \\
\mathrm{n}=25\end{array}$ & $\begin{array}{c}\text { L2(E) } \\
\mathrm{n}=25\end{array}$ \\
\hline $\begin{array}{c}\text { Phase III } \\
\text { Y6-42 days) }\end{array}$ at 42 days & g & $\mathbf{1 6 5 . 7 1}$ & $\mathbf{1 9 9 . 6 2}$ & $\mathbf{1 8 9 . 6 4}$ \\
\hline $\begin{array}{c}\text { Average daily consumption } \\
\text { during entire } \\
\text { experimental period }\end{array}$ & g & $\mathbf{1 0 4 . 6 8}$ & $\mathbf{1 1 7 . 6 2}$ & $\mathbf{1 1 3 . 3 2}$ \\
\hline
\end{tabular}


Tab. 10. Evolution of fodder conversion index in broiler chickens during entire experimental period

\begin{tabular}{|c|c|c|c|c|}
\hline Age (days) & U.M & $\begin{array}{l}\mathrm{L}(\mathrm{M}) \\
\mathrm{n}=25\end{array}$ & $\begin{array}{c}\mathrm{L} 1(\mathrm{E}) \\
\mathrm{n}=25 \\
\text { YEA-SACC1026 } 0.1 \%\end{array}$ & $\begin{array}{c}\mathrm{L} 2(\mathrm{E}) \\
\mathrm{n}=25 \\
\text { YEA-SACC1026 } 0.25 \%\end{array}$ \\
\hline \multirow{2}{*}{$\begin{array}{c}\text { Phase I } \\
\text { (1-14 days) }\end{array}$} & \multirow{2}{*}{$\mathrm{Kg} / \mathrm{Kg}$} & 1.40 & 1.31 & 1.36 \\
\hline & & 100 & 93.57 & 97.14 \\
\hline \multirow{2}{*}{$\begin{array}{c}\text { Phase II } \\
\text { (15-35 days) }\end{array}$} & \multirow{2}{*}{$\mathrm{Kg} / \mathrm{Kg}$} & 1.62 & 1.52 & 1.59 \\
\hline & & 100 & 93.82 & 98.14 \\
\hline \multirow{2}{*}{$\begin{array}{c}\text { Phase III } \\
\text { (36-42 days) }\end{array}$} & \multirow{2}{*}{$\mathrm{Kg} / \mathrm{Kg}$} & 5.12 & 2.94 & 3.43 \\
\hline & & 100 & 57.42 & 66.99 \\
\hline \multirow{2}{*}{$\begin{array}{c}\text { Final average } \\
\text { on entire period }\end{array}$} & $\mathrm{Kg} / \mathrm{Kg}$ & 2.71 & 1.92 & 2.12 \\
\hline & $\%$ & 100 & 70.84 & 78.22 \\
\hline
\end{tabular}

\section{CONCLUSIONS}

From presented data can be observed that the use of YEA-SACC 1026 probiotic as supplement in chickens' nutrition determined a substantial improvement of production and consumption indices. The body weight at 42 days in lot L1(E) was with $16.26 \%$ greater given to control lot L(M), and in lot L2(E) was with $8.32 \%$ greater given to control lot $\mathrm{L}(\mathrm{M})$. The average daily gain on entire experimental period in lot L1(E) was greater with $39.09 \%$ given to control lot $\mathrm{L}(\mathrm{M})$, and in lot $\mathrm{L} 2(\mathrm{E})$ was greater with $23.51 \%$ given to control lot $\mathrm{L}(\mathrm{M})$. Although the fodder consumption in lot L1(E) was greater with $12.36 \%$ given to control lot $\mathrm{L}(\mathrm{M})$ and in lot L2(E) greater with $8.25 \%$ given to control lot $\mathrm{L}(\mathrm{M})$, the fodder conversion index was in lot L1(E) greater with $29.16 \%$ given to control lot $\mathrm{L}(\mathrm{M})$, and in lot L2(E) was greater with $21.78 \%$ given to control lot L(M).

The use of YEA-SACC 1026 probiotic in chicken broilers' fodder is recommended in two doses $(0.1 \%$ and $0.25 \%)$ because it improves the weight gain and fodder conversion.

\section{REFERENCES}

1. Gao J, Zhang HJ, Yu SH, Wu SG, Yoon I, Quigley J, Gao YP, Qi GH. (2008). Effects of yeast culture in broiler diets on performance and immunomodulatory functions. Poult Sci 87(7): 1377-1384.

2. Gheisari AA, Kholeghipour B (2010). Effect of dietary inclusion of live yeast (Saccharomyces cerevisiae) on growth performance, immune responses and blood parameter of broiler chickens. Revista electronica de Veterinaria, 9: 1695-7504.

3. Huang X, Cai H, Liu G, Yan H, Chang W, Zhang S (2016). Effects of dynamic segmentation of nutrient supply on growth performance and intestinal development of broilers. Animal Nutr 2(4): 276-281

4. Nawaz H, Abbas Irshad M, Mubarak A (2016). Effect of probiotics on growth performance, nutrient digestibility and carcass characteristics in broilers. J Anim Plant Sci 26(3): 599-604.

5. Paryad A, Mahmoudi M (2008). Effect of different levels of supplemental yeast (Saccharomyces cerevisiae) on performance, blood constituents and carcass characteristics of broiler chicks. African Journal of Agricultural Research 3(12): 835-842. 